\title{
From Bureaucracy to Profession: Remaking the Educational Sector for the Twenty-First Century
}

\section{Citation}

Mehta, Jal. 2013. “From Bureaucracy to Profession: Remaking the Educational Sector for the Twenty-First Century." Harvard Educational Review 83 (3) (September): 463-488. doi:10.17763/ haer.83.3.kr08797621362v05.

\section{Published Version}

10.17763/haer.83.3.kr08797621362v05

\section{Permanent link}

http://nrs.harvard.edu/urn-3:HUL.InstRepos:33063300

\section{Terms of Use}

This article was downloaded from Harvard University's DASH repository, and is made available under the terms and conditions applicable to Open Access Policy Articles, as set forth at http:// nrs.harvard.edu/urn-3:HUL.InstRepos:dash.current.terms-of-use\#OAP

\section{Share Your Story}

The Harvard community has made this article openly available.

Please share how this access benefits you. Submit a story.

Accessibility 
From Bureaucracy to Profession:

Remaking the Educational Sector for the Twenty-First Century

\author{
Jal Mehta \\ Harvard Graduate School of Education \\ Final Pre-Publication Version \\ 2013 \\ Published in Harvard Educational Review \\ Official citation:
}

Mehta, Jal. "From Bureaucracy to Profession: Remaking the Educational Sector for the $21^{\text {st }}$ Century." 2013. Harvard Educational Review, 83(3): 463-488. 


\section{From Bureaucracy to Profession: Remaking the Educational Sector for the Twenty-First Century}

In this essay, Jal Mehta examines the challenges faced by American schooling and the reasons for persistent failure of American school reforms to achieve successful educational outcomes at scale. He concludes that many of the problems faced by American schools are artifacts of the bureaucratic form in which the education sector as a whole was cast: "We are trying to solve a problem that requires professional skill and expertise by using bureaucratic levers of requirements and regulations." Building on research from a variety of fields and disciplines, Mehta advances a "sectoral" perspective on education reform, exploring how this shift in thinking could help education stakeholders produce quality practice across the nation.

Achieving successful educational outcomes at scale is arguably the greatest challenge for American schooling. In this essay, I suggest that we are asking the wrong question. When reforms don't grow as far or as fast as we hope, we ask, "What's wrong with the reform?" when instead we should ask, "What's wrong with the sector?" The root problem is that the educational sector as a whole is organized around a core system that functions as a bureaucracy rather than as a profession; we are trying to solve a problem that requires professional skill and expertise by using bureaucratic levers of requirements and regulations. Many of the specific problems we see today - wide variability in levels of teacher skill from classroom to classroom, failure to bring good practices to scale across sites, the absence of an "educational infrastructure" to support practice, the failure to capitalize on the knowledge and skill of leading teachers, and the distrustful and unproductive relationships between policymakers and practitioners-are byproducts of the form in which the educational sector was cast. Particularly as the demands on schooling increase, with all students expected to be able to think critically in order to participate 
in modern life, we need to transform the system from a Progressive Era bureaucracy into a $21^{\text {st }}$ century profession.

In the pages that follow, I look at the roots of the organization of the contemporary education sector: how its initial form affected its development, the implications of that form for our current difficulties in achieving successful practice at scale, and the ways in which a reconceived educational sector would be better equipped to help all students achieve. This argument builds on and integrates research from diverse arenas-work on the technical requirements of teaching, the sociology of the professions, the historical development of schooling in the United States, and comparative research on international educational leaders- to advance a sectoral perspective on why we have struggled to achieve widespread success in American education and how a remade educational sector might better address our problems in the future.

\section{Changing the Lens: From Scaling Up Programs to Remaking the Sector}

There are two major perspectives that are frequently employed in the discussion of educational improvement at scale. One takes the program or policy as the unit of analysis. From this view, the initial question is whether the policy is achieving its intended impact on outcomes. A program or policy that demonstrates success in a particular context is then chosen to be replicated in other contexts. The logic is appealing because it allows for experimentation before implementation on a wider scale and draws on the logic of science and the tools of rigorous evaluation. The approach is also fundamentally consistent with democratic imperatives, as it has elected legislators making laws and unelected civil servants (in this case, teachers) implementing them. 
For all of these virtues, the problem with this logic is that it doesn't work well, at least if the goal is real improvement at scale. The typical pattern is as follows. Some set of attributes is shown to produce a result at a pilot site on a small scale. Legislators become excited about the idea and seek to translate what happened at the initial site into a program or policy that is intended to achieve what the pilot did. But when the initiative is rolled out at broader scale, actors across the many sites do not have the same level of expertise and investment in the idea as the actors involved in the pilot (Schneider \& McDonald, 2007). Important pieces of detailed practical knowledge (métis) that made the initial idea work are not captured by the program's relatively broad directives. Differences in context make what worked in place A not work as well in place B. Evaluations conclude that the net effect of the program as a whole is very small or zero (Rossi, 1987), but that some sites had significant positive results. Those successful sites tend to be the ones that have strong leaders and more buy-in and that either showed greater fidelity to the original design or discovered ways to adapt it to their contexts. The success of these few becomes the basis for the next initiative, with an effort to isolate "what worked" at these sites and to make it the foundation for the next round of policies, beginning the cycle anew. Charles Payne (2008) calls this the "so much reform, so little change" pattern of school improvement efforts.

The second perspective on improvement at scale embodies a more bottom-up logic, focusing less on policy and more on organizational replication. The idea, again, is to identify what works at one site and then to have the parent organization—such as a charter management organization - slowly and carefully copy these elements at additional sites. In the best-case scenario, very specific attention is paid to the detailed practical knowledge needed to make the initiative work, and this knowledge is transferred from site to site (Peurach, 2011). 
The strengths and weaknesses of this approach are the mirror image of the previous one. The primary strength is that with a slower pace, more attention to detail, more layered processes of knowledge transfer, and, potentially, the ability to choose sites with more favorable circumstances, these networks can, at their best, deliver significantly larger results on conventional assessments than the programmatic approach. Even leaving aside pedagogical criticisms, such as those levied at "no excuses" schools (Goodman, 2013), there are weaknesses to this approach on its own terms. One is that in order to be successful, you need to get many different things exactly right — and thus the pace is, necessarily, extremely slow. For instance, in almost twenty years of existence, leading charter networks still have only about one hundred schools - in a nation with 100,000 schools (Toch, 2009). Another limitation is that, to date, much of what makes these enterprises run is the selection of young people willing to work long hours, again making it difficult to conceive how this approach might succeed at real scale. Overall, neither top-down nor bottom-up approaches have been able to produce good outcomes across the nation.

I argue here that these are not the only two options. We would be better off taking a wider view and seeing the problem from a sectoral perspective rather than from either a programmatic or organizational replication perspective. From the sectoral perspective, the key to improvement is not individual initiatives but, rather, the features that organize the work of the sector as a whole. These features include: (1) who is drawn to work in the sector, how they are selected, and how they are trained; (2) whether there is an accumulating knowledge base that guides the work; (3) whether there are processes in place to ensure that knowledge is consistently used at the delivery site; and (4) whether the aforementioned steps are aligned around an overarching system of accountability. 
All fields need a way of accomplishing these four functions, but different occupations vary greatly in how successful they are at each and in where they choose to place their emphasis. Viewing American medicine as a sector, for example, we see that there is a high degree of selectivity in who enters the field, extensive training drawing on a highly developed and robust knowledge base, and organizational processes such as hospital rounds that ensure that this knowledge is utilized in everyday practice, but there are relatively weak back-end mechanisms of overall accountability (i.e., there is no "No Patient Left Behind"). Conversely, in American education, while we are now overinvested in outcome accountability, we haven't built the needed human capital, knowledge, or organizational processes that would achieve these goals. While medicine and education are not exact analogues - among other differences, medicine is a more scientific field and one in which the ends are less contested - the comparison is useful because it highlights the ways in which education is comparatively much less robust in developing the processes needed to consistently produce skilled work.

From a sectoral perspective, American education is organized backward in comparison to both medicine and higher performing educational systems around the world. By organized backward, I mean that we seek to accomplish on the back end-by holding teachers accountable — what we did not do on the front end - building a system that might be reasonably expected to consistently create good results. In the American educational system, we do not recruit teachers from the top tier of academic achievement; we provide them with only limited training, equip them with little usable knowledge, and send them to work in schools that, by international standards, have high levels of child poverty and weak welfare state supports. These factors contribute to greatly varying student outcomes, both from teacher to teacher and from school to school, with particularly dismal results in schools that serve large proportions of high- 
poverty students. In turn, policy makers look at these failing schools and seek to intervene, most directly by holding schools and teachers accountable for results. This creates a climate of distrust between policy makers and practitioners, with policy makers seeking to monitor and direct practitioners they feel are failing to provide students a decent education and practitioners resenting policy makers for what they see as misplaced blame and ill-informed demands from afar. This is the downward spiral the American educational system is in today: underprofessionalization and weak performance lead to increased regulation, external accountability, and distrust, which in turn make the profession less attractive to talented people, thus starting the spiral anew.

What the American education sector needs is the opposite-an upward spiral, which characterizes a number of the nations with strong performance on international educational comparisons. The pattern in these nations is to recruit teachers from the top third of college graduates, prepare them extensively, and provide welfare-state support for high-poverty students (Barber \& Mourshed, 2007; OECD, 2010). The dynamics of these systems are very different from what we see in the United States: talented and prepared teachers, combined with motivated and well-supported students, produce good outcomes at the level of the school, which leads external actors, including policy makers, to see schools more as partners in improvement and less as failing entities that need to be monitored and controlled. These dynamics produce a higher level of professionalization and internal accountability, which creates trust and decreases regulation from higher powers, a shift that makes the education field more attractive to academically strong candidates, thus continuing the positive cycle (Mehta, 2013). 
Offering a more promising approach to questions of scale, the sectoral perspective also brings into relief a number of aspects of the context that are largely invisible from the more traditional programmatic perspective. While the programmatic view takes as given the current structure of the system-states overseeing districts, districts overseeing schools, schools overseeing teachers-the sectoral perspective imagines that there are different ways in which practitioners and the state might interact, particularly if those practitioners were more organized as members of a full-fledged profession. Further, while the programmatic view draws attention to the actors that have formal educational authority (states, districts, principals, and teachers), the sectoral view asks us to look more broadly at the wide range of actors that currently do, or could potentially, influence schooling, including, for example, teacher preparation institutions, teacher unions, researchers, the philanthropic community, and the large commercial sector that provides much of American education's curricula, assessments, and professional development. From the sectoral perspective, the central questions focus on the level of quality exhibited by each of these actors and the extent to which they, on the whole, are aligned in service of educational goals.

Finally, the programmatic perspective is largely silent on questions of politics, history, and power. Its assumption is that although politics play a role when the initiative is chosen, the following stage would ideally be a nonpolitical process of implementation. In contrast, the sectoral perspective foregrounds how different actors in the field have developed, why they do what they do, and how they interact with one another in a complex and contested political environment. The contention of the sectoral perspective, then, is that significant, large-scale improvement will require engaging these various actors (or creating new actors) to work together in aligned ways that are consistent with their organizational interests and that also advance the sector as a whole. 


\section{The Form of the School System: Bureaucracy versus Profession}

Deep historical roots underlie the organization of the contemporary educational sector. While a full accounting of these antecedents is beyond the scope of this article, a brief sketch of the historical context can help to illuminate the nature of the challenges we face today.

Particularly important to this history is the distinction between bureaucratic and professional modes of organizing work. In ideal type, a bureaucracy is organized around a logic of managerial control, with power largely concentrated at the top and workers seen as largely interchangeable at the bottom. In such a system, standardization is ensured by creating elaborate rules and procedures that cover the range of circumstances that actors in the system are likely to confront. Such a system is appropriate for routine work, like that in a factory, in which the processes can be fairly well specified and the actions fairly clearly prescribed. By contrast, a professional model is more appropriate for non-routine work that requires high levels of skill and expertise (Rowan 1990). Teaching requires teachers to have a thorough knowledge of their subjects and of how students understand those subjects, as well as a capacity for real-time interactive decision making in unpredictable situations. In fact, Philip Jackson (1968) has estimated that teachers make thousands of micro decisions in the course of a given day. For these reasons, teaching is more appropriately thought of as professional work, characterized by deep levels of knowledge and expertise, professionally shared standards of appropriate practice, and the use of judgment and discretion in applying that common knowledge to particular situations.

Table 1 illustrates the differences between the two modes of social organization. While many scholars have investigated these differences (Perrow, 1967, Rowan, 1990), the language and organization of this table draws most heavily on Mintzberg (1993). Differences in the technical requirements of the work, skilled or routine, are in turn connected to differences in how 
the work is organized. In particular, the mechanism that ensures consistency of outcomes varies: in bureaucratic work it is following routine processes (e.g., on assembly lines), while in professional work it is building knowledge of how the work should be done, training people in that knowledge, licensing only those who have mastered that knowledge, and then creating ongoing norms and standards that guide the work in practice. Academia, for example, uses the $\mathrm{PhD}$ to certify that new entrants have met the initial expectations of a given field and then peer review to ensure that ongoing work is consistent with the norms of that field. These differences in the nature of work and its organization are linked to differences in political power. In bureaucratically organized enterprises, power is largely concentrated with those who exercise managerial oversight; but in professions, the profession assumes significant power on the basis of its expertise, which then enables it to advocate for itself with respect to the state.

\section{[Insert Table 1 About Here]}

Further complicating matters is that American teaching sits within a particular type of bureaucracy. It is not really a factory-style model in which a teacher's every move is tightly prescribed by external entities, although there have been periods when policy makers have tried to script curricula and turn teaching into assembly line work, including the way some districts and schools have implemented No Child Left Behind (Au, 2011).. The more general historical pattern in American teaching, however, has been a loosely coupled bureaucracy that is hierarchical in its distribution of authority but fairly weak in its specification of the actual procedures that govern practice (Weick, 1976). District and, later, state and federal officials prescribe what has to be learned, at what pace, and with what consequences, but then teachers are given considerable freedom to decide how to reach these ends. In this arrangement, creating a common technical core that might reliably produce such outcomes is not really anyone's 
responsibility. Ironically, this arrangement is then celebrated as "tight on ends" and "loose on means," (National Governors Association, 1986; Osborne \& Gabler, 1992) as if it gives everyone an appropriate role in the system, when in fact what it frequently means in practice is that the higher power is asking the lower power to do something that neither really knows how to do.

\section{Progressive Era Origins: The Allure of the Factory Model}

The origins of this somewhat peculiar arrangement lie in Progressive Era notions of teaching, administration, and social organization. In one generation, between 1890 and 1920, the modern school system was created by a group of civic elites known as the "administrative progressives," who transformed a nation of one-room schoolhouses into a network of district school systems. Influenced by prevailing Taylorist models of business organization, which sought to use ideas of scientific management to control workers and increase efficiency, mostly male superintendents were empowered as CEOs to lead school systems, while mostly female teachers were expected to follow the rules and programs their superintendents prescribed. Training for teachers was relatively minimal, and teachers did not possess any political power to push back against directives from above (Tyack, 1974; Tyack \& Cuban, 1995).

Many of the people who were most important in this movement resided in emerging departments and schools of education, which, for the most part, cast themselves with the lot of the administrators rather than the teachers (Callahan, 1962). Underlying this view was the idea that the complex practice in need of attention in education was not teaching but social administration. Harvard president Charles Eliot, speaking for the faculty, said, "The faculty in common with most teachers in England and the United States feel but slight interest or confidence in what is usually called pedagogy" (Lagemann, 2000, p. 63). The training of 
administrators provided an opportunity for education departments to produce a new class of mostly male professionals whose role was widely discussed as equivalent to that of a CEO. The development of this type of professional allowed education departments to aspire to parity with professions like medicine, law, and engineering and to eliminate the stigma that came with training a largely feminized workforce. As Edward Cubberley described it in his classic 1916 textbook, Public School Administration:

School supervision represents a new profession, and one which in time will play a very important part in the development of American life. In pecuniary, social, professional and personal rewards it ranks with the other learned professions, while the call for city school superintendents of the right type is today greater than the call for lawyers, doctors or ministers. The opportunities offered in this new profession to men of strong character, broad sympathies, high purposes, fine culture, courage, exact training and executive skills . . are today not excelled in any of the professions, learned or otherwise. (pp. 130-131)

Cubberley (1916) suggested that superintendents should be expected to complete college and one year of graduate school and that many should continue to the $\mathrm{PhD}$, while teachers needed only a high school education and a two-year training program. For a university discipline seeking to gain its footing, developing a science of school administration that required extensive training of a largely male administrative corps provided a way for education departments and schools to claim equivalence with higherstatus fields like medicine and law.

A related issue was the organization of knowledge production and use. Consistent with the aforementioned divisions between university researchers and teachers, what developed was a largely quantitative and statistical program of educational research carried out by scientists in the 
university, who would convey it to highly trained school administrators, who would then implement it through teachers operating at the bottom of the totem pole. This hierarchical approach is encapsulated by testing expert Edward Thorndike in his 1906 text The Principles of Teaching: "It is the problem of the higher authorities of the schools to decide what the school shall try to achieve and to arrange plans for schools' work which will attain the desired ends. Having decided what changes are to be made, they entrust to the teachers the work of making them" (cited in Lagemann, 2000, p. 60).

This system enabled education departments and schools to do more basic and less applied research in ways that mirrored their more prestigious arts and sciences colleagues; what it did not do was consistently produce the kind of practical knowledge about teaching needed by the field.

\section{The Road Not Taken: Organizing as a Profession}

An alternate mode of more professional social organization might have reversed a number of these assumptions. John Dewey argued for such a model, and the failure of his efforts reveals the strength of institutional imperatives pulling in the opposite direction. In Dewey's famous laboratory school, founded while he was at the University of Chicago, the school itself served as a primary opportunity for research. In Dewey's (1896) words, a lab school should bear "the relation to work in pedagogy that a laboratory bears to biology, physics, or chemistry" (p. 417). Research, in Dewey's view, should be carried out in schools, in contrast to Thorndike's view that time spent in schools was largely a "bore" (Lagemann, 2000, p. 59). Further, Dewey did not seek to partition the roles of researcher and teacher, arguing instead that both were interested in the same goal of improving learning. Rather than have "one expert dictating educational methods and subject-matter to a body of passive, recipient teachers," Dewey 
advocated "the adoption of intellectual initiative, discussion, and decision throughout the entire school corps" (Lagemann, 2000, p. 50).

Evident in Dewey's ideas is an early form of what it might look like to build a profession based on practical knowledge: teachers and researchers working alongside one another to produce new knowledge; knowledge that is organized in part around practical questions coming from the field rather than entirely out of the heads of university researchers; a healthy, interdependent relationship between basic and applied knowledge; and teachers treated as professionals capable of taking "intellectual initiative" and organizing their own work rather than implementing the ideas of others.

But while his ideas were widely discussed, Dewey's model of research as a function shared between researchers and school teachers was rejected by university education departments, which were seeking to elevate themselves precisely by distancing themselves from teachers. As Ellen Lagemann (2000) puts it:

His position was very much at odds with the hierarchy then developing among educational institutions, a hierarchy in which mostly male university scholars of education would generate the knowledge needed by mostly male school administrators, who would, in turn, be responsible for dictating and supervising the instructional methods to be used by teachers in schools, especially the mostly female teachers involved at the elementary levels. (p. 51).

These Progressive Era decisions produced the system we see today: university researchers developing knowledge that is more useful for advancing the social science disciplines than for addressing problems of practice; administrators using this knowledge as the basis for the policies and programs they implement; and teachers resisting what they see as illinformed mandates from afar. This system is consistent with our respect for science and the 
higher status we afford to universities in relation to $\mathrm{K}-12$ schools, but it has been fundamentally ineffectual because it seeks to address a problem of inadequate professional knowledge and skill through a process of bureaucratic administration and implementation (Mehta, 2013).

Finally, as became clearer over the course of the century, the field's organization as a bureaucracy rather than as a profession affected not only the core of its practice but also its politics by creating a strong state and a weakened practitioner class. Established fields like medicine and higher education organized themselves as self-regulating guilds that were primarily responsible for training, licensing, and setting ongoing standards of practice (Jencks \& Riesman, 1968; Starr, 1982). In so doing, they were able to assume considerable control over their domains. In contrast, in K-12 education, the absence of such professional organization has resulted in teachers functioning essentially as "street-level bureaucrats," responsible for implementing decisions from above rather than as respected experts whose voices are heard and heeded.

\section{Long Shadows of the Progressive Era: Organizational Imprinting and Path Dependence}

In characterizing patterns of historical evolution, sociologists have observed that there is frequently a process of organizational imprinting when the conditions under which organizations are founded create a fairly stable organizational DNA, which persists even as circumstances change (Stinchcombe, 1965). In a related vein, political scientists have argued that there is frequently a process of "path dependence" in which initial decisions (e.g., whether to organize health care as a public good or a private market) affect subsequent events by creating the norms, structures, and distribution of power that in turn shape later decisions and actions (Hacker, 1998; Pierson, 2000). In the case of American education, we can see organizational imprinting as the 
shaping of organizational identities of key actors in the education sector and path dependence as the pattern of interactions among these actors that has developed over time to produce the outcomes we see.

With respect to organizational imprinting, I examine the impact of the bureaucratic organization of the sector on three groups: teacher organizations/unions (the professionals), education schools (the knowledge producers), and district/state/federal officials (the state). Teachers were initially organized into weak associations (which included administrators as well as teachers) that gave them little power with respect to superintendents and school boards. Teachers were paid whatever local boards decided to pay them and had little say over the conditions of their work. Beginning in the early 1960s, as more men entered teaching and legal changes supported the organization of public-sector employees, teachers began to organize along the industrial union model we see today. In this model, the representatives of teachers, as in bluecollar unions, advocated for increased pay and protected workers from capricious decisions of administrators but declined responsibility for school outcomes or governance, which were judged to fall on the other side of the labor-management divide. This was a sensible response given the initial positioning of teachers as weak actors at the bottom of the implementation ladder who, in the absence of strong union organization, would be paid even less and would have even less control over their work.

At the same time, this response has had considerable costs. By organizing as industrial unions, teachers have fundamentally limited their responsibility for and control over the quality of their work. Policies that seem sensible from a union perspective-limiting work hours, protecting members from firing, "step and lane" pay scales—are frequently seen as getting in the way of improving school quality, because the protection of worker rights can come at the cost of 
making decisions that are best for schools and students (Moe, 2011). This way of positioning teachers can and does undermine their credibility as political actors (Mehta \& Winship, 2010).

Recognizing this dynamic amid a crisis of school quality in the mid-1980s, American Federation of Teachers (AFT) president Albert Shanker argued that unions needed to take a more professional direction if they were to be legitimate political actors. "Reform or be reformed," he argued, and efforts by Shanker and others did yield a number of initiatives that sought to move the unions in a more professional direction. A group of locals known as the Teacher Union Reform Network (TURN) sought to explicitly reformulate themselves along the lines of what they called "professional unionism" (Kahlenberg, 2007). Their aim was to pair bread-and-butter issues around pay and working conditions with issues focused on the quality of practice, including creating standards for teaching, peer assistance and review, and, in some cases, having teachers exercise joint management of schools with administrators and being held accountable for the results. Professional unionism, however, has faced a significant uphill struggle: after more than twenty years of effort, there are fewer than two dozen locals in TURN. Particularly as external pressures for accountability and even union-busting heighten, it is difficult for union leaders to win elections without promising to vigorously defend the rights of teachers as traditionally defined. As organizational imprinting theory predicts, teacher unions were created to protect the rights of their constituents in a specific earlier context, and efforts to recast them to serve more professional functions in our current context have been a hard sell (Kerchner, Koppich, \& Weeres, 1997; Moe, 2011; Toch, 1991).

There is a parallel story about education schools, with respect to both the production of knowledge and the training of teachers. Education schools assumed their modern form in the Progressive Era, when they moved away from their earlier interest in philosophy toward the 
emerging social science disciplines. As with other professional schools, education schools had, in theory, a dual responsibility to the academy and to the larger field and were charged with producing knowledge that would be respected by scholars as well as suitable for the training of practitioners. But a number of factors frustrated the ability of education schools to fully carry out this dual mission. The most important is that education schools aligned themselves with the norms of the academy: hiring researchers with $\mathrm{PhDs}$, publishing in academic journals, and orienting themselves toward the development of increasingly refined social scientific knowledge and theory (Clifford \& Guthrie, 1988). The most selective education schools evolved by emphasizing the training of administrators over the training of teachers. In contrast to other fields, the leading education schools did not seek to train those who would actually work in the field; that function was mostly left to less exclusive schools. Generally, teacher training has been widely faulted for its emphasis on theory over practice, perhaps not surprisingly since the professors responsible for it are usually trained as scholars and not recruited for their pedagogical expertise (Lanier \& Little, 1986; Levine, 2006).

Foment around school reform in the eighties led to an effort for significant change. A consortium of nearly one hundred leading universities came together with the aim of transforming their teacher education programs to make them more relevant to practice. The Holmes Group, named after former Harvard Graduate School of Education dean Henry Holmes, issued a series of reports critiquing the problems with existing teacher education. The reports proposed that there be closer links to practice, particularly in the form of professional development schools that could also serve as sites for training teachers and as labs for research. Nearly thirty years later, the analyses of the Holmes Group's work again suggest the lasting power of the initial template. Despite having the commitment of a number of leading education 
schools, significant foundation funding, and three widely cited reports, when the Holmes Group actually turned to reform, it floundered. As one postmortem described it,

Ten years after the publication of Tomorrow's Teachers, the teacher education curriculum in programs across the United States had changed little, few universities supported professional development schools or other close collaborations with $\mathrm{K}-12$ schools, and the traditional teacher licensure system was intact. (Forzani, 2011, p.10)

The reasons for this resistance to change were again consistent with organizational imprinting. The retrospective analyses suggested that faculty at selective education schools did not have the inclination or know-how to teach pedagogy, resented the shift toward practical research away from broader social scientific research questions, and embraced norms of academic freedom and autonomy over the idea of shared program design. For their part, school districts were not eager to turn their schools over to universities and had little experience or interest in the kind of co-design such a project would have required. Efforts to create new, more integrated professional development schools that would bridge existing boundaries between practitioners and researchers were stymied by the existing roles and patterns that had been developing in the sector since the Progressive Era (Forzani, 2011; Fullan, Galluzzo, Morris, \& Watson, 1998).

For their part, district, state, and federal policies have developed in ways that are also consistent with how these government agencies initially developed their roles. In the absence of the kind of countervailing powers that exist in medicine, academia, or other more developed professions, officials have felt fairly free to develop programs, requirements, and other rules that are to be implemented by teachers for the benefit of students. This compliance-oriented approach has had some benefits, particularly in the case of protecting students' rights. For instance, the use 
of government power has been unquestionably beneficial in ensuring the rights of minority students, fair access to services for students with disabilities, and appropriate instruction for English language learners.

But what has been more difficult has been employing this same tool not only to establish floors but also to move toward ceilings - to not only prevent harm but also to produce quality schooling (Wise, 1979). As David Cohen and Susan Moffitt (2009) argue, in the years since the passage of the initial Elementary and Secondary Education Act in 1965, the ambitions for what is to be achieved have increased substantially, but what government can actually do using its levers has remained largely the same. The result has been a sizable gap between what the government seeks to do and what it can actually accomplish, largely because tools like creating standards, assessments, and accountability from afar do little to build the needed expertise to reach desired targets.

If we put these three stories into motion and integrate them with one another, we can get a clearer picture of how we arrived at where we are today. For its first half-century (roughly 1910-1960), the system the progressives created worked somewhat harmoniously, because the expectations for what schools needed to produce were fairly limited. Loose coupling preserved enough teacher autonomy to make teachers feel that they were in control of their own domain while school boards and superintendents had enough formal power to preserve the idea of a supervisory system and democratic control. Education schools trained administrators and teachers, a function that paid their bills while allowing their professors to research what they liked. Teachers were mostly women, who had few other employment options and were also frequently not the breadwinners in their families, and thus their low pay did not prompt significant resistance. By 1960, most white students graduated with a high school degree, which, 
regardless of how much they had actually learned, would certify them for middle-class occupations in manufacturing and other jobs. A smaller number of more advantaged kids went to better public schools or to private schools and then on to college. The result was that many different actors got what they needed, even if the sector as a whole was not doing much to maximize the learning of all of its students (Meyer \& Rowan, 1977).

As the expectations for schooling have increased in the last fifty years, the limits of this way of constructing the sector have become increasingly apparent. Driven by a combination of civil rights imperatives and the economic shift from an industrial to a postindustrial economy, policy makers now expect all students to achieve academically at fairly high levels. But the ways that these goals have been pursued say more about the pre-established tracks in which these actors are operating than they do about how a sector would need to be constructed to produce such outcomes. Policy makers and other external actors, sitting at the top of loosely coupled hierarchical bureaucracies, have sought to tighten coupling and increase pressure for performance, using the levers they have at their disposal-largely standards, assessments, and accountability. Teachers, through their unions, have for the most part resisted calls for external accountability on the grounds that such demands diminish their professional autonomy and unfairly blame them for factors outside of their control. Such a stance only hardens policy makers' desire for accountability, which in turn only increases practitioners' resentment of policy makers. Meanwhile, the lion's share of education schools have continued mostly unchanged: no one is really responsible for producing knowledge that might feasibly guide the work to better outcomes. In addition, expanded professional opportunities for women have contributed to the field losing a captive labor pool and thus having to face the increased challenge of recruiting talented practitioners into its ranks. All told, the result is that we continue 
to pursue the challenge of quality through limited regulatory mechanisms while evading the core problem of attracting the needed human capital, building the knowledge base, and creating structures for using that knowledge that might, in combination, actually produce better outcomes at scale. As path dependence predicts, our decisions are understandable in light of our history, but not well adapted to our current needs.

These challenges have become particularly pressing as the field seeks to move toward achieving more ambitious instruction, or "deeper learning," for all of its students. Research consistently suggests that the dominant pattern in American instruction over the past century has been to ask students to answer close-ended, apply-and-recall kinds of questions that sit at the bottom of the traditional learning taxonomies (Cohen, 1988; Cuban, 1984; Goodlad, 1984; Elmore, 1996). Recent findings from the Measures of Effective Teaching Project (2012) suggest that these patterns persist: across thousands of sample classrooms, they found that more than 60 percent of classes were competently managed but that only one in five featured ambitious instruction that asked students to reason and to answer more open-ended questions. The more we ask teachers to engage students in the kind of critical thinking and reasoning that is a staple of twenty-first-century life, the more imperative it becomes to have an expert teaching force that itself is prepared to engage in this kind of work.

\section{Downward Spirals: Consequences of the Weak Professionalization of the Field}

The shape of the sector as a hierarchical bureaucracy rather than as a full-fledged profession has had a varied set of implications for education today. In particular, it has contributed to an unhealthy relationship between educational practice inside schools and the outside forces that seek to shape that practice. The result has been antagonism and mistrust 
between policy makers and practitioners, with little of the hoped-for improvement in practice at scale.

A good place to start is the absence of a consistently codified, shared knowledge base and accompanying professional infrastructure that guide work in other fields (Cohen, 2011). A large part of what defines professionals is the expectation that they will handle routine work in ways that are relatively consistent with the standards of their respective fields. This is why we select a qualified professional to fix a broken elbow, land a plane, or draw up a will. In the absence of such standards, teaching has evolved an ethos of defensive professionalism that emphasizes individual autonomy — "I am a professional and so I should do exactly as I think is right"-rather than the more mature professionalism of other fields, in which shared expert knowledge lays the foundation for practice (Lortie, 1975). Professionals in more mature fields, like medicine, do exercise their individual judgment and discretion, but they do so in the context of applying a common knowledge base to particular situations. Education, in contrast, has evolved around an "all-teachers-need-to-invent-good-practice-for-themselves" ethos, which, in the absence of building on and contributing to a shared public knowledge base, is counterproductive to efforts to create quality at scale (Mehta, Gomez, \& Bryk, 2012).

Teachers are protective of their autonomy in this way precisely because they are so frequently bombarded with external directives that have little immediate practical utility. Teachers sit at the bottom of an administrative hierarchy and have to do what their superiors direct, regardless of whether what is prescribed is well thought out or well suited to their particular circumstances. In addition, in the absence of a well-developed knowledge base to guide practice, the sector attracts providers offering "ten-point plans" to achieve their preferred educational outcomes; it also swings wildly between extremes in its approach to teaching core 
subjects such as reading and math. In fields like law and medicine, in which professional development is done almost exclusively by members of the profession, a shared technical language allows such development to add to existing knowledge, and practitioners get some choice about what they want to learn more about. By contrast, in education, teachers are frequently sent to programs chosen by their principal or district, where the professional development is frequently offered by nonteachers and where the ideas seemingly cycle endlessly with little connection to an existing knowledge base. Not surprisingly, evaluations of professional development in education have suggested that these programs only rarely have any noticeable impact on practice (Hill, 2007).

A related consequence of the absence of a strong profession is that education is tossed around like a political football. One reason it is difficult to mount sustained improvement campaigns in education is what a number of observers have dubbed the "spinning wheels" phenomenon: superintendents and programs cycle through rapidly, as one set of plausible ideas gives way to another, and new ideas are often introduced before old ones are given a real chance to work (Hess, 1998; Payne, 2008). But international comparisons to more professionalized education systems suggest that this kind of cycling is not a necessary feature of school reform in the public domain. While it is appropriate for politics to figure in public schooling, in countries that feature stronger educational professions and ministries, public input is combined with professional expertise to yield better results and more sustained campaigns for improvement (OECD, 2010).

The result in American education is a downward spiral of practitioners and policy makers. From the point of view of teachers, policy makers and district administrators are generally out of touch with the realities in the classroom; they lurch from one priority to another 
for largely political reasons and unfairly wield power despite their limited useful knowledge. Popular books in the teacher literature, such as Weapons of Mass Instruction (Gatto, 2009), liken policy to a war on students and teachers. Experienced teachers frequently express understandable cynicism about cycling superintendents and fads of the moment. Conversely, from the perspective of administrators and policy makers, it appears irresponsible not to try to intervene when they confront evidence about the wide variation in teacher skill from classroom to classroom and the underperformance of students, particularly poor and minority students. So intervene they do, starting the downward spiral anew.

\section{Upward Spirals: How to Reassemble the Sector and Professionalize the Field}

What the American education system needs is the opposite of the dynamic described above; it needs an upward spiral in which the internal and the external are seen more as partners than adversaries. Initial levels of professional skill and expertise in schools create a more fertile ground on which to try out new ideas. Those ideas are then offered less in the spirit of compliance and more in the spirit of offering new knowledge that might be well-suited to solving a problem of practice. Both parties accept that the other is operating in good faith and may have something valuable to contribute to the process, thereby creating a culture of respect between the parties that is wholly absent in American education. The external power in these cases is often not only part of the state but also part of the profession; therefore, it is both more knowledgeable about education practice and more able to maintain consistency over time, reducing the kind of faddish lurching between extremes that is characteristic of American schooling. By creating a professional rather than a bureaucratic orientation, we could escape the downward spiral that we 
have been in and move toward the kind of upward spiral that is characteristic of higherperforming nations.

Comparative research on the Program for International Student Assessment's (PISA) leading nations is still in its early stages, but there is preliminary evidence that a number of topperforming nations organize their educational work in a way that is relatively similar to that of stronger professions in the United States. Countries as varied as Singapore, Finland, Korea, and Canada take some similar steps in organizing their educational sectors: they recruit their teachers from the top third of their college cohorts, give them extensive and highly practical training, support their schools with strong welfare states, and then depend more on internal professional accountability than on external lay accountability to produce outcomes. The state does play an important role in these processes, but the education ministries that run many of these PISA leaders are as much a part of the larger education profession as they are part of the government, meaning that their role is less to monitor and punish schools and more to work with them in a process of shared professional improvement. In so doing, they also seek to create levels of trust, legitimacy, and respect among actors at different levels of the system that are entirely absent in the United States (Darling-Hammond, 2010; Levin, 2008; OECD, 2010).

No two countries are entirely alike, and it would be a mistake to assume that strategies that have worked in other contexts can simply be imported wholesale into the United States. While these countries are different from one another, none of them shares America's troubled history of race, its skepticism of government, and its sheer size and diversity of views and opinions. More structurally, the United States also has a more decentralized structure than many of these other nations, which means that the locus for action is distributed across more actors. Still, as much as it would be a mistake to think that external strategies can be uncritically 
imported, it would be equally provincial to think that we have nothing to learn from the rest of the world. It is also striking that the picture that emerges across these countries looks relatively similar in its core attributes to those of the stronger professions within the United States.

Even given differences in context, there are ways that the United States could move to transform its education sector in a more professional direction. There are four interrelated aspects to the needed changes that correspond to the four core functions in any field. We need to make changes to the human capital pipeline, changes to the knowledge base, changes to the organizational processes that ensure that the knowledge is used, and changes to the role of districts and the state, from compliance monitors to partners in the social improvement processes. None of these things will be easy, but they are all necessary if the goal is sectorwide improvement.

\section{Building an Expert Workforce}

With respect to human capital, we need to take seriously the entire pipeline: attracting, selecting, training, and retaining our next generation of teachers. The current focus on teacher evaluation serves only to sort our existing teachers; we will not make progress in the long run without a strategy that addresses all aspects of the pipeline. The goal should be much higher standards for entry to teacher education programs and then higher standards for credentialing to teach. Underlying this approach is a commitment to becoming more selective in who can become a teacher. The goal is not necessarily to select teachers simply with higher test scores; over time, we expect that a much more fine-grained system can be developed that will increase our predictive power about who is likely to become a good teacher. Higher standards will cause 
shortages initially, but it will be critical to hold the line if the goal is to signal that teaching is a serious profession.

The stars may be converging to create some progress on this point. In the past year, the American Federation of Teachers (2012), the National Education Association (2012), and the Council of Chief State School Officers (2012) have each released a major report calling for raising the standards of entry for initial teachers. The AFT proposal is the one getting the most attention, as it calls for a "bar exam" for teaching akin to what exists in law, medicine, and other developed fields. This is a very promising set of developments because it places the unions squarely behind an agenda of raising standards for the entire teaching profession rather than one of protecting their least competent members. In the longer run, such an exam might be the starting point for a more virtuous cycle: if the public were persuaded that tenured members of the profession had demonstrated their ability to teach, then respect for the profession would go up, which might eventually lead to higher salaries, which, with the combination of status and money, would make it easier to draw stronger applicants in the future.

A related set of changes is needed in the training of teachers. The explosion of a pluralism of different providers of teacher education over the past twenty years-including alternative certification programs, urban teacher residencies, and teacher training programs run by schools themselves - has greatly expanded the range of experimentation about how to train new teachers. Initial research suggests that there is much greater variation within these broad types than across them but that the particular programs which work well have an unsurprising set of common elements. Successful programs all tend to select people with content training in what they are going to teach, give them careful and extended practice and feedback on their work in schools, and teach them to use data and to reflect carefully on their practice. Policy should 
continue to embrace pluralism of different types of training institutions; but as standards become clearer, some will survive and others will not on the basis of whether their graduates are consistently able to pass the bar and become teachers.

Teacher training also could take a page from medicine and develop an apprenticeship program akin to the medical residency system. Currently, teacher training institutions are responsible for teacher preparation during student teaching or the first year of teaching, and districts are responsible for induction after that. It would make more sense to unite these functions under single institutions that would oversee teachers' development during their first three years of teaching. Master teachers would be responsible for this training and would need to have sufficient time built into their schedules (akin to hospital attending physicians) to oversee new teachers.

New teachers would be given increased levels of responsibility over time, beginning with team teaching with master teachers. Then they would teach a partial load (one class for teachers in middle and high schools and part of the day for teachers in elementary schools) and use the rest of the time for feedback, reflection, and integration of what they are learning about teaching with their experiences in the classroom. Over the second and third year, they would take increasing responsibility for more classroom practice, commensurate with their developing skills and competencies. Teacher residency programs, like the Boston Teacher Residency, have recently developed "teaching hospital" schools that attempt to move in this direction. Creating such a laddered and closely supervised teacher training process would prepare people well to demonstrate the needed teaching skills to become tenured teachers (Mehta \& Doctor, 2013). 


\section{Codifying a Knowledge Base}

Changing who become teachers and how they are trained will matter little if there is not a publicly shared and vetted knowledge base that underlies that training. At their core, professions rest on their respective knowledge bases. In the absence of specialized expertise, there is no basis for the claim for professional licensing. Research suggests that there are three kinds of knowledge most relevant for classroom teaching: content knowledge about the subject matter, pedagogical knowledge about how to teach, and pedagogical content knowledge about how to teach particular subjects (Shulman, 1987). Expert teachers not only possess these kinds of knowledge, but they also know how to integrate them in real situations; like experts in other domains, they are able to quickly diagnose situations and draw on a wide repertoire of techniques in response (Chi, Glaser, \& Farr, 1988; Cimino, 1999; Livingston \& Borko, 1989). Good teaching also has an affective dimension, as the ability to develop a warm but demanding rapport with students is critical for success (Grossman \& McDonald, 2008).

Developing a knowledge base that would inform such a complex, interactive, contextdependent, and value-conflicted enterprise is not easy. It is unlikely to take the clinical, relatively decision-free form we see in medicine (i.e., in the presence of symptoms $\mathrm{X}, \mathrm{Y}$, and $\mathrm{Z}$ we order test A, which will help us differentiate between treatment B and treatment C), because the realtime demands are too great and the impact of any given decision is highly context dependent (e.g., it is different to teach about conflicts over busing in Boston than it is to teach the same topic in Mississippi). But what a knowledge base could do is inform rather than drive decisions; we could know much more about how expert teachers create good climates in their classrooms, about what kinds of structures and supports students need as they undertake historical investigations, and about how to help students move toward greater oral proficiency in 
languages. This knowledge could stretch from micro questions about teacher moves to broader questions about how best to structure units or sequences of units to achieve increasingly deep understanding.

In the U.S. context, the major challenge in this domain is that there is no entity specifically charged with producing the knowledge we need. For the most part, researchers publish for other researchers; teachers develop practical knowledge but are not supported to regularly evaluate it or publicly share such vetted knowledge; and commercial curriculum designers produce what districts and states will buy without substantive regard for what would produce high-quality educational practice (Hiebert, Gallimore, \& Stigler, 2002). At the same time, there are many promising pockets, including charter networks producing their own knowledge about teaching, Internet platforms that allow teachers to share lessons, efforts by Teach for America to codify what they have found effective for their core members, independent researchers like Jon Saphier (2008) and his work on The Skillful Teacher, and, of course, some researchers who are particularly interested in pedagogical practice (Charlot, Tran, \& StemmCalderon, 2012).With a push from either the government or the philanthropic sector, it is possible to imagine education undergoing a process similar to what medicine underwent a century ago, where existing sources of knowledge become more integrated, vetted, and shared. It would also likely be helpful to build an educational equivalent to the National Institutes of Health, because if the goal is to have a full-time community of researchers devoted explicitly to producing knowledge relevant for practice, then having a major public commitment to this task is needed.

\section{Putting Knowledge into Practice}


Developing people and knowledge won't help much if there aren't consistent ways to get the knowledge into action in actual schools. To put it another way, training by itself is a weak lever for enforcing norms of good practice, because these norms need to be reinforced by the daily routines of the actual work. Schools have made some progress on this issue over the past twenty years in their greater use of data and in the creation of professional learning communities. The next step would be to further integrate these efforts into the knowledge base of the broader profession. We might imagine a world where one's relationship to knowledge varied on the basis of one's level of expertise. Beginning teachers would receive heavy doses of ongoing training from master teachers within their schools; intermediate teachers would work with one another to draw on the knowledge base and adapt it to their particular students and ideas; and advanced teachers would develop new units and ideas in collaboration with researchers to add to the field's stock of knowledge.

Finally, we need to change the relationship among schools and districts and states from a culture of distrust and compliance toward one of mutual respect and professional learning. The examples from other countries show that schools and higher levels of government can work in concert, with the issue in those systems being less about who controls what and more about how different parties can contribute in different ways toward shared outcomes. In the United States, such a cultural change would be both a cause and a consequence of the other changes in a professionalizing strategy. If the profession were more knowledgeable and internally organized, it would garner more respect from those higher in the system; in turn, if those higher in the system showed more respect for the profession, it would allow greater space for practitioners to experiment and grow and make it easier to attract talented people to the field. 


\section{From Here to There}

One of the challenges of historical analysis is that it seems to promote the fatalistic sense that history is destiny. Institutions that are organized to do one sort of thing are unlikely to do another: unions protect their members, districts promulgate rules, university researchers write mostly for other university researchers. It is much easier to describe what a different kind of system might look like than to explain how we might get from here to there.

At the same time, it is worth remembering that institutions are not monolithic and often have strands within them that can be mobilized for change. Teacher unions can and have supported elements of a professionalism agenda, including higher standards for entering teachers, more extensive induction processes for new teachers, peer assistance and review programs through which teachers mentor and evaluate fellow teachers, and career ladders that differentiate roles for teachers at different levels of skill and experience. Far-sighted districts like Montgomery County, Maryland, and Long Beach, California, have shown the way in which carefully developed standards, extensive capacity building for teachers, and the creation of respectful relationships between unions and district administrators can both produce sustained labor peace and gradually improve student outcomes (Childress et. al, 2009; Austin, Schwartz and Suesse, 2004). In a different vein, "portfolio" districts like New Orleans, New York, Baltimore, and others have shown the power of devolving much greater authority to individual schools, empowering local educators, and shifting the district role away from its command-andcontrol origins. Meanwhile, there has been increasing recognition by leading researchers of the importance of university-practice collaborations, leading to the creation of interstitial institutions like the Chicago Consortium on School Research and the Strategic Education Research Partnership, research entities that are directly oriented to the needs of policy and practice. The 
largest accrediting agency of traditional education schools has recently made the inclusion of greater focus on practice an important part of teacher education requirements.

If existing institutions cannot transform themselves in useful ways, they may be challenged or even replaced by new ones that are better adapted to the needs of the times. Groups like Teach Plus and Educators 4 Excellence are relatively new organizations that seek to represent teachers outside of the unions, advocating for policies that build on the strengths of skilled teachers to improve outcomes for students. Teacher residency programs and school-run teacher training institutions are new entrants to the teacher preparation market that are much more explicitly focused on preparing teachers for practice than the university programs they seek to replace. Charter management organizations, ranging from pedagogically traditional ones like Uncommon Schools to progressive ones like High Tech High, are developing knowledge out of the practice of their leading teachers and seeking to incorporate it into their teacher training programs. On all of these fronts, traditional institutions are facing outside challengers, who are currently modest in scale but whose role may increase if they are shown to be more successful than those they seek to supplant (Mehta \& Teles, 2011).

There are also external developments that are moving the varied actors in the direction advocated here. The combination of the higher standards advocated by Common Core State Standards and the fact that No Child Left Behind was unable to realize its more modest goals has led to increased interest in raising teachers' skills and knowledge if we are to achieve our increasingly more amibitious goals. The increasingly public nature of the PISA results are themselves a factor in generating support for this agenda, because the results thus far have been interpreted to show that the leading nations are pursuing the kind of teacher professionalization strategy I advocate here. 
In a large and decentralized system like ours, it is unrealistic to expect an overnight transformation, however, it is possible that a set of concerted efforts pulling in the same direction can gradually yield a quite different kind of sector. Two final examples illustrate the possibilities. U.S. health care was the paradigmatic case for the theory of path dependence - the fact that the United States had initially evolved its provision of health care through a private market rather than as a public good theorists argued, made it much more difficult for subsequent reform to move toward universal care because organized interests were empowered to prevent such changes. This logic appeared airtight — until it wasn't, when the Affordable Care Act of 2010 passed. The way that it passed was not in the form that many universal health care advocates hoped for-single-payer health care run by the government, which, they argued, comparative evidence suggested would be both less expensive and more efficacious. Instead, the program that passed was a public-private compromise dealing in existing insurers and essentially creating a hybrid form out of present reality rather than what a system designer might have created starting from scratch. Similarly, shifting education in a more professional direction will necessitate building out of our existing institutions rather than creating a new system out of whole cloth.

An example from Ontario, Canada, shows what might be possible. From 1997 to 2003, an acrimonious relationship between provincial leadership and teachers and their unions was pervasive. The government ran ads on television demonizing teachers, reduced professional development time by half, and cut funding; unions responded with numerous and lengthy strikes. In 2003, with the election of a new premier, Dalton McGuinty, a new team formed that was determined to make peace with the unions and work together toward the long-term goal of improving student achievement. The leadership, unions, and other groups began to meet 
quarterly to discuss key issues; they hammered out a long-term labor peace in 2005. Provincial leadership actively looked for win-win issues with the unions, such as more extensive common planning time and funding of an extra position for an in-school dropout prevention coordinator. These stable conditions paved the way for a longer-term capacity-building strategy around literacy and numeracy, as well as for a push to raise high school graduation rates. By 2010 , the graduation rate had increased from 68 percent to 79 percent, and the percentage of elementary school students passing math, literacy, and science exams had increased from 55 percent to 70 percent (Mehta \& Schwartz, 2010). The climate within the system had also greatly improved, with surveys of teachers revealing that they were as happy to be working within the system as they had been at any point in their tenure. While the scale of the challenge is large, these examples suggest that even within a relatively short period of time, significant changes in both the outcomes and the ethos of a system are possible. 
Table 1

Bureaucratic and professional modes of organization

\begin{tabular}{|c|c|c|}
\hline Dimension & Bureaucracy & Profession \\
\hline Nature of work & Routine & Skilled \\
\hline $\begin{array}{l}\text { Coordinating } \\
\text { mechanism }\end{array}$ & $\begin{array}{l}\text { Standardization of work } \\
\text { processes }\end{array}$ & $\begin{array}{l}\text { Standardization of skills through } \\
\text { training and licensing }\end{array}$ \\
\hline Source of authority & Managerial control & Knowledge of the work \\
\hline Location of authority & Administrative class & Practitioner class \\
\hline $\begin{array}{l}\text { Responsibility of } \\
\text { practitioners }\end{array}$ & $\begin{array}{l}\text { Implement directives } \\
\text { from above }\end{array}$ & $\begin{array}{l}\text { Self-regulating guild: field sets } \\
\text { standards; individual practitioners } \\
\text { exercise judgment and discretion } \\
\text { within those standards }\end{array}$ \\
\hline Political dynamics & $\begin{array}{l}\text { Hierarchical: strong state, } \\
\text { weak practitioner class }\end{array}$ & $\begin{array}{l}\text { Countervailing powers: profession } \\
\text { and state on relatively equal footing }\end{array}$ \\
\hline
\end{tabular}

Source: Adapted from, and building on, Mintzberg (1993). 


\section{$\underline{\text { References }}$}

American Federation of Teachers [AFT]. (2012). Raising the bar: Aligning and elevating teacher preparation and the teaching profession. Washington, DC: Author.

$\mathrm{Au}, \mathrm{W}$. (2011). Teaching under the new Taylorism: High-stakes testing and the standardization of the $21^{\text {st }}$ century curriculum. Journal of Curriculum Studies 43(1), 25-45.

Austin, J, Schwartz, R \& Suesse, J. 2004. Long Beach Unified School District (A): Change that leads to improvement (1992-2002). Cambridge: Public Education Leadership Project.

Barber, M., \& Mourshed, M. (2007). How the world's best-performing school systems come out on top. London: McKinsey.

Callahan, R. (1962). Education and the cult of efficiency. Chicago: University of Chicago Press.

Charlot, J., Tran, D., \& Stemm-Calderon, Z. 2013. Theories of learning and a body of knowledge. Unpublished working paper, Harvard Graduate School of Education.

Chi, M., Glaser, R., \& Farr, M. J. (Eds). (1988). The nature of expertise. Hillsdale, NJ: Lawrence Erlbaum.

Childress, S. et al. (2009). Leading for equity: The pursuit of excellence in the Montgomery County schools. Cambridge: Harvard Education Press.

Cimino, J. (1999). Development of expertise in medical practice. In R. Sternberg \& J. Horvath (Eds.), Tacit knowledge in professional practice (pp.101-119). Mahwah, NJ: Lawrence Erlbaum.

Clifford, G. J., \& Guthrie, J. W. (1988). Ed school: A brief for professional education. Chicago: University of Chicago Press.

Cohen, D. (1988). Teaching practice: Plus ça change. In Philip W. Jackson (Ed.), Contributing to educational change: Perspectives on research and practice (pp. 27-84). Berkeley, CA: McCutchan.

Cohen, D. (2011). Teaching and its predicaments. Cambridge, MA: Harvard University Press.

Cohen, D. K., \& Moffitt, S. L. (2009). The ordeal of equality: Did federal regulation fix the schools? Cambridge, MA: Harvard University Press.

Council of Chief State School Officers. (2012). Our responsibility, our promise: Transforming educator preparation and entry into the profession. Washington, DC: Author.

Cuban, L. (1984). How teachers taught: Constancy and change in American classrooms. New York: Teachers College Press.

Cubberley, E. P. (1916). Public school administration. Boston: Houghton Mifflin. 
Darling-Hammond, L. (2010). The flat world and education. New York: Teachers College Press.

Dewey, J. (1896). The University School. University Record (University of Chicago), 1, 417419.

Elmore, R. (1996). Getting to scale with good educational practice. Harvard Educational Review, 66(1), 1-26.

Forzani, F. (2011). The work of reform in teacher education. Dissertation Abstracts International.

Fullan, M., Galluzzo, G., Morris, P., \& Watson, N. (1998). The rise and stall of teacher education reform. Washington, DC: American Association of Colleges for Teacher Education.

Gatto, J. (2009). Weapons of mass instruction: A schoolteacher's journey through the dark world of compulsory schooling. Gabriola Island, British Columbia: New Society

Goodlad, J. (1984). A place called school: Promise for the future. New York: McGraw Hill.

Goodman, J. (2013). Charter management organizations and the regulated environment: Is it worth the price? Educational Researcher, 42(2), 89-96.

Grossman, P., \& McDonald, M. (2008). Back to the future: Directions for research in teaching and teacher education. American Educational Research Journal, 45(1), 184-205.

Hacker, J. (1998). The historical logic of national health insurance: Structure and sequence in the development of British, Canadian and U.S. medical policy. Studies in American Political Development, 12, 57-130.

Hess, F. (1998). Spinning wheels: The politics of urban school reform. Washington, DC: Brookings Institution.

Hiebert, J., Gallimore, R., \& Stigler, J. (2002). A knowledge base for the teaching profession: What would it look like and how can we get one? Educational Researcher, 31(5), 3-15.

Hill, H. (2007). Learning in the teacher workforce. Future of Children, 17(1), 111-127.

Jackson, P. (1968). Life in classrooms. New York: Holt, Rinehart, \& Winston.

Jencks, C., \& Riesman, D. (1968). The academic revolution. Garden City, NY: Doubleday.

Kahlenberg, R. (2007). Tough liberal: Albert Shanker and the battles over schools, race and democracy. New York: Columbia University Press.

Kerchner, C., Koppich, J., \& Weeres, J. (1997). United mind workers: Unions and teaching in the knowledge society. San Francisco: Jossey-Bass.

Lagemann, E. (2000). An elusive science. Chicago: University of Chicago Press. 
Lanier, J., \& Little, J. W. (1986). Research on teacher education. In M. Wittrock (Ed.), Handbook of research on teaching (3rd ed., pp. 527-559). New York: Macmillan.

Levine, A. (2006). Educating school teachers. Washington, DC: Education Schools Project.Levin, B. (2008). How to change 5000 schools: A practical and positive approach for leading change at every level. Cambridge, MA: Harvard Education Press.

Livingston, C., \& Borko, H. (1989). Expert-Novice differences in teaching: A cognitive analysis and implications for teacher education. Journal of Teacher Education, 40(4), 36-42.

Lortie, D. C. (1975). Schoolteacher: A sociological study. Chicago: University of Chicago Press.

Measures of Effective Teaching Project. (2012). Gathering feedback for teaching. Seattle: Gates Foundation.

Mehta, J. (2013). The allure of order: High hopes, dashed expectations and the troubled quest to remake American schooling. New York: Oxford University Press.

Mehta, J., \& Doctor, J. (2013). A board exam for teaching. Phi Delta Kappan, 94(7), 8-13.

Mehta, J., Gomez, L., \& Bryk, A. S. (2012). Building on practical knowledge: The key to a stronger profession is learning from the field. In J. Mehta, R. B. Schwartz, \& F. M. Hess (Eds.), The futures of school reform. Cambridge, MA: Harvard Education Press.

Mehta, J., \& Schwartz, R. (2010). Ontario, Canada: Reform to support high achievement in a diverse context. In A. Scleicher \& R. Hopper (Eds.), Strong performers and successful reformers in education: Lessons from PISA. Paris: OECD.

Mehta, J., \& Teles, S. (2011). Jurisdictional politics: A new federal role in education. In F. Hess \& A. Kelly (Eds.), Carrots, sticks, and the bully pulpit: Lessons from a half-century of federal efforts to improve America's schools. Cambridge, MA: Harvard Education Press.

Mehta, J \& Winship, C. (2010). "Moral power.” In S. Hitlin and S. Vaisey (Eds.), Handbook of the sociology of morality (pp. 425-438). New York: Springer.

Meyer, J. W., \& Rowan, B. (1977). Institutionalized organizations: Formal structure as myth and ceremony. American Journal of Sociology, 83(2), 340-363.

Mintzberg, H. (1993). Structure in fives: Designing effective organizations. Englewood Cliffs, NJ: Prentice Hall.

Moe, T. (2011). Special interest: Teachers unions and America's public schools. Washington, DC: Brookings Institution.

National Education Association [NEA]. (2012). Transforming teaching: Connecting professional responsibility with student learning. Washington, DC: Author. 
National Governors' Association. Center for Policy Research, Thomas H. Kean, Lamar Alexander, and Bill Clinton. (1986). Time for results: The governors' 1991 report on education. Washington, D.C.: Author.

Osborne, D \& Gaebler, T. (1992). Reinventing government: How the entrepreneurial spirit is transforming the public sector. Reading, Mass.: Addison-Wesley.

Organisation of Economic Co-operation and Development [OECD]. (2010). Strong performer and successful reformers in education: Lessons from PISA for the United States. Paris: OECD.

Payne, C. (2008). So much reform, so little change: The persistence of failure in American public schools. Cambridge, MA: Harvard Education Press.

Perrow, C. (1967). A framework for the comparative analysis of organizations. American Sociological Review 32(2), 194-208

Peurach, D. (2011). Seeing complexity in public education: Problems, possibilities and success for all. New York: Oxford University Press.

Pierson, P. (2000). Increasing returns, path dependence, and the study of politics. American Political Science Review, 94(2), 251-267.

Rossi, P. (1987). The iron law of evaluation and other metallic rules." Research in Social Problems and Public Policy, vol 4: 3-20.

Rowan, B. (1990). Commitment and control: Alternative strategies for the organizational design of schools. Review of Research in Education, 16(1), 353-389.

Saphier, J, Haley-Speca, M, \& R. Gower. (2008). The skillful teacher: Building your teaching skills. Acton, MA.: Research for Better Teaching, Inc.

Schneider, B., \& McDonald, S. (Eds). (2007). Scale-up in education: Issues in practice. Lanham, MD: Rowan \& Littlefield

Shulman, L. (1987). Knowledge and teaching: Foundations of the new reform. Harvard Educational Review, 57(1), 1-21.

Starr, P. (1982). The social transformation of American medicine. New York: Basic Books.

Stinchcombe, A. L. (1965). Social structure and organizations. In J. G. March (Ed.), Handbook of organizations (pp. 142-193). New York: Rand McNally.

Toch, T. (1991). In the name of excellence: The struggle to reform the nation's schools, why it's failing, and what should be done. New York: Oxford University Press.

Toch, T. (2009). "Sweating the big stuff: A progress report on efforts to scale up the nation's best charter schools." Unpublished document received from author. 
Tyack, D. (1974). The one best system. Cambridge, MA: Harvard University Press.

Tyack, D., \& Cuban, L. (1995). Tinkering toward utopia: A century of public school reform. Cambridge, MA: Harvard University Press.

Weick, K. (1976). Educational organizations as loosely coupled systems. Administrative Science Quarterly, 21 (1), 1-19.

Wise, A. (1979). Legislated learning: The bureaucratization of the American classroom. Berkeley: University of California Press. 